\title{
Influence of Job Enlargement On Employee Performance In The Railway Industry In Kenya
}

\author{
Mary Mwihaki Gichuki \\ University of Nairobi. Nairobi, Kenya \\ Dr. Mercy Gacheri Munjuri \\ Department of Business Administration \\ School of Business, University of Nairobi. Nairobi, Kenya
}

\begin{abstract}
There are numerous factors that affect the level of job satisfaction and this is highly influenced by the design and the nature of tasks assigned to the employees. The purpose of this study was to determine the influence of job enlargement on the performance of employees in the railway industry in Kenya. The study was done in one of the major railway companies in Kenya. A descriptive survey research design was adopted and the target population comprised all the 2000 employees of the railway company, out of which a sample of 400 employees was selected using systematic random sampling technique. Primary data was collected using structured questionnaires. Descriptive statistics and regression analysis approaches were employed in data analysis. The findings revealed that job enlargement contributed positively in enhancing employee performance. Regression results showed that task structuring and work arrangement resulted into increased employee performance while work meaningfulness was inversely linked to employee performance. The researcher recommends that the government should institute training and development programs to nurture employee knowledge and skills on how employee duties can be structured to boost their understanding of organizational processes and procedures. Organizations should consider implementing flexible structures that accommodate environmental changes and as such employees can identify tasks more efficiently and achieve their set targets. Future researchers can replicate this study in the private sector to establish whether the results realized under this study would hold.
\end{abstract}

Key words: Job Enlargement, Employee Performance, Railway Industry, Kenya

\section{INTRODUCTION}

Organizational performance is affected by various factors including satisfaction of job level, which is influenced by the nature and design of the assigned tasks. Employee needs in an organization vary and in the same way the needs are to be met in different ways. Armstrong (2003) defines job design as the methods of performing tasks, aimed at meeting the needs of the organization as well as the job holder. The author further reveals that job design ensures that the assigned tasks match their skills and interests. Job enlargement being one of the forms of job design is aimed at improving job satisfaction, improve output, work quality and reduce employee grievances and dissatisfaction. According to Atkinson (1984) job enlargement aims at meeting the personal needs of employees by re-organizing and restructuring work such that the nature and content of the assigned tasks meets the social and personal needs of employees. Job enlargement if well applied is very important in any organization because it enhances positive effects on the productivity of its employees. Hellgren and Sverke (2001) posit that as a result of the increase in the pressure of work it is worthwhile to transform employees work activities and expose them to broader levels. Job enlargement impacts on motivational and satisfaction levels and organisational level of commitment. Job enlargement increases 
employee interest to perform the job. Routine tasks without change might make employees bored in the work place and impact negatively on their level of motivation (Dessler, 2005).

Employee needs are no different and an employee will want to derive full satisfaction from the work they engage in daily. Employees want to fulfill their physiological, safety, belonging, esteem and self-actualization needs. Kenya has an extensive network of different transportation channels all of which are managed and regulated by the Ministry of transport. The railway system in Kenya links the nation's ports and major cities as well as connecting the country to other nations like Uganda. There are a number of airports too that serve both the nation locally and internationally. The diverse activities in the transport industry create a challenging environment to implement job enlargement. This is because logistics of which transport is a component contains other job activities that need to be carried out to ensure the movement of goods and services is efficient, some of these tasks are related while others are very different.

Infrastructure is one of the main variables of development based on the Kenya Vision 2030 manual. The long-term development policy aspires for the nation to have good connection of roads, airports, and railway, telecommunication as well as water and sanitation facilities. Efficient transport is pivotal in facilitating economic development both in the global and national level. Transport availability impacts global development in that it can be a boost or barrier. A good transport network has enabled the country to move into a twenty four hour economy. Movement of goods and services from one region to another has been eased and essential facilities like hospitals, schools, banks and markets have also been established in areas with good networks. Investment into the transport sector helps develop a strong relationship between the consumers and producers. It improves performance and thus mitigating overall firm outcome. It widens market scope and enhances production and economies of scale. Performance and productivity are increased as time for movement of raw materials from one point to another is reduced; it broadens the market creating a more diverse platform for outputs, energy and labor (PPIAF- World Bank, 2011).

The railway company has numerous positions which are related as duties performed in one department will in one way or the other influence the duties performed by another department and overall influence the performance of another department. Job enlargement is based on how closely the roles are related or similar to each other. For example locomotive drivers whose role is to ensure movement of load from the supplier to the customer have their roles enlarged to include ensuring the locomotives are in good working condition as well as ensuring documentations handed over to them on the load they are transporting are correct. Sales managers are given extra roles of ensuring all goods are invoiced and the same delivered to the correct customers and loadings are done other than just connecting the clients to the organization through their sales duties. Job rotation is also encouraged as staff can be assigned jobs in other departments as long as they have the qualifications and experience. This has led to increased employee morale, efficiency and output.

Researchers in the past have studied job enlargement and the various employee and organizational outcomes. Shakeela et al (2012) explored the effectiveness of job expansion on satisfaction of employees in Pakistan and established that job enlargement impacted positively on employee satisfaction especially job performance. Mohamoud (2015) assessed the contribution of job increase on employees' motivation and satisfaction, and found that well managed and designed jobs cause employees to feel interested and as a result get motivated and satisfied. Employees expressed that enlargement widens abilities and skills while providing staff with a chance to communicate and learn from others. Sushil (2014) conducted a 
study with an aim of determining the effect of job upgrade, job enlargement and work life balance. It was concluded that if implemented properly the job becomes a motivation in itself. This enhances job satisfaction and thus improves work-life balance. It also increases commitment and overall effectiveness and efficiency of organizations making them sustainable.

Studies done on job enlargement were conducted under specific set conditions. The conditions given in the various studies had contradictions and this posed a danger of having biased opinions on the value of job enlargement. The aim of this research was to fill the knowledge gap by attempting to answer the question; what is the influence of job enlargement on employee performance at the railway company?

\section{Theoretical Foundation of the study}

\section{LITERATURE REVIEW}

This study was guided by motivational theories specifically Herzberg two factor theory and Maslow's hierarchy of needs theory. One of the primary interests of organizations is to satisfy the needs of employees, which is described in the Herzberg's (1957) Two Factor Theory. Based on the approach, employee motivation is greatly influenced by their attitude towards work. The theory holds that employee attitude towards work is determined by the work situations that define how they feel about their jobs.

According to Hertzberg, the factors that promote employee motivation differ from those that cause their job dissatisfaction. This implies that satisfaction cannot be considered as an opposite of dissatisfaction. Employee motivation is influenced by the ability of the company to meet physiological and psychological needs. The former refers to monetary compensation that enables employees to pay for basic necessities such as food and shelter while the latter refers to factors such as working conditions that promote employee career development. Employee satisfaction is determined by intrinsic or motivating factors while dissatisfaction results from hygiene factors or extrinsic motivators.

Hertzberg argues that the extrinsic motivating factors have no effect on the satisfaction of employees but their absence results into dissatisfaction. These factors include job security, salary and other fringe benefits. The intrinsic motivators, on the other hand, provide employees with extra motivation to work hard. They include involvement in decision-making and recognition. Both the extrinsic and intrinsic motivators are independent such that the presence of one factor does not affect the other.

The Two Factor Theory holds that organizations should combine both the hygiene and motivating factors for optimal employee productivity. Businesses should structure the jobs in a way that makes it interesting to the employees. Aspects such as job enlargement are useful in promoting employee motivation because they are offered a wide variety of tasks that reduce monotony and boredom. Additionally, the employees are empowered make decisions about their jobs, which motivate them further.

Although the Two Factor Theory provides important insights about employee motivation and productivity, critics argue that it is inaccurate. The theory assumes that job satisfaction results to increased employee productivity, which is not true. However, despite the weakness, the theory cites that motivation comes from within the employees based on the working conditions. Thus, managers need to consider both the hygiene and motivating factors in 
organizations. Jobs should be structured in a way that employee are offered opportunities to develop their careers as they meet organizational needs.

Abraham Maslow was aimed at understanding what motivated individuals. Maslow (1963) postulates that individuals are motivated to accomplish certain wants; some wants are more of a priority than others. Maslow maintains that employees have a set of motivational systems that are unrelated to rewards or insensible desires and when a need is filled an individual seeks to satisfy the next one and order follows. In accordance to theory of hierarchy of needs, this is exactly what is happening even today. This theory is instrumental in understanding individual motivation, training and personal growth.

The argument put forward by Maslow, is that managers could drive motivation in an organizational setting through accomplishing the wants of the employees and prioritizing the most important needs to them. Needs are organized into a hierarchical manner and it is only after a meeting a need at a lower level that that a worker would develop the urge to have the next need on the hierarchy satisfied (Tay \& Diener, 2011).

Going by Maslow's theory, it is impossible for managers to successfully apply a single motivation theory to enhance the productivity of their workforce. For the managers to maximize the performance of employees, it is crucial to design their jobs in a manner that meets the social and personal needs of the employees as well as provide financial rewards. Although the Maslow's theory provides important insights about motivation and organizational productivity, it has limitations. Critics argue that application of Maslow's theory is difficult because different people have various perceptions about their needs. The employees also have various relationships between the motivating factors and their needs. For example, employees who are motivated financial rewards consider the earning power as an important aspect of their self-esteem thus work harder to increase their earning opportunities. Contrary, employees who are motivated by extrinsic factors such as recognition see monetary rewards as mere cash aimed at meeting their security needs. Such employees desire to achieve more than just monetary gains.

\section{Job Enlargement}

Job enlargement can be described as horizontal job loading which is an act of assigning employees additional duties within their work spectrum and increasing activities done (Dessler, 2005). This helps to reduce boredom arising from doing repetitive work daily and it helps motivate workers in an organization. Hulin and Blood (1968) explain that job enlargement enhances the productivity of employees because it allows them to set their desired limits, control their quality, correct their mistakes and plan their work. Gupta (2008) cites that job enlargement makes the job more interesting by increasing its scope on the basis of number of tasks performed. The widened and more complex job is expected to satisfy the higher order needs of employees. Job enlargement entails adding the number of tasks in a job with an aim of meeting the diverse social and personal needs of the employees. The reorganization and restructuring of work is based on motivational theories to ensure that the new tasks in the job design meet the employees' expectations. Job enlargement also considers the elements of work performance and job satisfaction to ensure a balance between organizational needs and employee needs.

While it is important to ensure that personal and social needs of employees are fulfilled, it is crucial to consider organizational performance too. As a trait of job design, job enlargement reduces the monotony of work by increasing the number of tasks performed. The formulation of effective job enlargement involves considering two reasons; personal satisfaction of 
employees and optimal use of resources. According to Wales (2000), job enlargement principles are concerned with specialization and division of labor. The repetitive nature of the divided tasks results into specialization, which increases employee productivity and job satisfaction. Job enlargement has two major reasons to be considered that is improving the level of satisfaction by individuals which is obtained from their work and maximizing on available organizational resources and to use it overcoming barriers towards effective performance. However, division of labor may be counterproductive because of boredom and alienation experienced by the employees.

\section{Forms of Job Enlargement}

Job enlargement can be done through task structuring, job arrangement and checking at the meaningfulness of a job. These forms of job enlargement have been discussed as follows:

\section{Task structuring}

Task structuring can be defined as the level at which a task is made clear to its staff who are assigned to perform it. Task structuring entails the magnitude to which jobs are defined and have a detailed description of processes. Employees are made aware of the steps they should take in performing a job for them to be successful. According to House (1996) when employees' tasks are well defined and organized the employees gets motivated to work independently since they are aware on the direction to take. Employees will efficiently achieve their goals and those of the company when work procedures are made clear. Management role entails making analysis and structuring tasks where necessary to remove any form of barriers that might deter workers from executing their duties and finishing their work.

Task structuring also refers to the number of task components into a given responsibility or responsibilities. Complexity involved in a given job could be a reflection of several tasks that might need to be carried out, skills and the competencies needed as well as the decisions that need to be made to make predictions regarding the consequences of a given decision (Lutans, 2011). A complete integrated job consists of three elements namely, planning, executing and measuring each of the tasks involved. Task structuring makes up one of the three components of leadership theory which stipulates that the objective of a leader is to provide a superior task structure in order to keep employees motivated and efficient. A clear distribution of duties in line with set goals enhances employee understanding of their job and this gives them confidence to effectively execute their roles. Task structuring also allows a leader to recognize problems and hurdles in a job and re-design it accordingly.

\section{Job arrangement}

Hackman and Oldham (1975) explains that job arrangement aims at ensuring integration of different elements of a job; planning, controlling and executing. The management and team leaders are entrusted with the tasks of planning and controlling the job while the employees are responsible for execution of the tasks. Among the leading factors that promote job arrangement is job enlargement, whose main objective is to integrate the planning and controlling elements into the assigned tasks. Consequently, employees gain empowerment that promotes their career advancement and motivation. One of the leading merits of job arrangement is workers ability to achieve a balance between life and work. It refers to the perceptions that employees gain about the balance between their career and personal achievements. Good work life balance allows employees to balance between family care, personal time and career success with minimal conflict. For employers to take advantage of the high employee motivation that results from work life balance, they implement measures such as quality-of-work-life programs such as flexible work schedules. Through the flexible work 
schedules, employees are allowed to work when they can as long as the agreed hours of work are covered and the required job output is met. Workplace wellness includes things such as counseling, childcare and family support programs which when taken care of employees are able to concentrate fully on their jobs.

\section{Checking meaningfulness of a job}

According to Hackman and Oldham (1974) psychological holds that meaningfulness of job and aligning responsibilities to work productivity has a great influence on motivation, satisfaction of the job and performance. The job characteristic method provides implementing principles that can be used to enrich jobs in an organization. The model provides a set of 5 main traits of a job that include a variety of set skills, identity, importance of work, independence and feedback that impacts the work i.e. satisfaction, motivation, absenteeism and turnover.

Hackman and Oldham (1980) proposed that motivation was linked to an employee experiencing meaningfulness of job that is fundamental to intrinsic motivation. It is the responsibility given to the employee to prove themselves in a job through their performance and knowledge of the outcomes. An employee needs to the success story of work done to learn from their gaffes. As a result each of the three critical states is derived from the characteristic of the job. Knowledge of the outcomes is derived from the feedback and employee receives on their performance (Robertson, 1992).

\section{Employee Performance}

Performance is divided into organizational and employees' performance (Otley, 1999). Job performance in many organizations is however subjectively measured, that is it is not independently measured and will be dependent on other factors in the work environment. Job performance is regarded as the results obtained from the work of an employee (Hunter, 1986). Staff performance is the measure of whether a person executes their job duties and responsibilities satisfactorily. Employee performance can also be defined as how well employees carry out job related activities assigned to them in regard to facilities provided and their efficiency in utilizing such (Bruce, 2010). Campbell (1993) defines employee performance as a measure of how well an individual carries out tasks assigned to them all dependent on a single person. He further defines performance in relation to behavior which differentiates performance from outcomes. Outcomes result from external influences as well as an individual's outcome, which can be in the form of non-observable actions such as decisions and answers. However, performance is under an individual's control whether it is mental or behavioral.

Muhammad (2013) explains that employee performance is among the leading factors that influence an organization's success. The level of productivity of an individual employee is benefits both the employees and the organization. According to Bandura (1997) employees who record high performance show high levels of job satisfaction, mastery of job and high selfefficacy. The many rewards associated with high employee performance enhance their career opportunities (Van Scotter et al., 2000).

The significance of measuring performance is cited by Haden (2013), who explains that it should be conducted as an ongoing process. The author further explains that the performance evaluation should entail all the aspects of employee achievements and work ethics. Multiple tools of measuring performance have been developed and businesses have the liberty of choosing the one that best suits them. However, the 2014 Global Assessment Report points that organizations use either talent metrics or objective metrics to track performance. Rachel Scott, 2016 proposes five metrics for measuring an employee's performance. She says that 
performance can be measured by looking at the attendance of an employee i.e. punctuality and consistency in carrying out their duties. How helpful employees are to their colleagues and other stakeholders. The output of an employee is determined by their efficiency in carrying out tasks, their initiative and the quality of work they give.

\section{Indicators of Employee Performance}

Cuenin (1897) defines performance indicators as numerical value that shows the quantitative value or performance of a given system. However, performance is not only measured by quantitative means, but also qualitative indicators (Massen, 1990). The direction of an indicator shows the level of performance. Favorable performance is indicated by the movement of the indicator in one direction while the movement in the opposite direction is indicative of poor performance. Success is often the repeated periodic achievement of operational goals. Choosing the right key performance indicators (KPIs) relies on what is important to the organization and importance is dependent on the department within an organization which is measuring it. Performance indicators are routinely associated with performance improvement initiatives.

Different management frameworks such as the balance score card are used to select KPIs. Becker (2005) declared that the elements in the human resource score card are key leading indicators for the success of a workforce. Key performance indicators have always been assigned to each perspective in the strategy map but are being adapted in the entrepreneurial sector as well. Gerathy (2003) observed that according to their experience performance indicators are valid and effective when applied in a comprehensive and consistent manner. Griffin (2004) pointed out that there should be a direct link from the overall organizational goals to the performance indicators. Appleby (1994) suggests that employees' performance is indicated by industrial peace within organizational goals due to minimized strikes, lockouts and other malpractices which can affect productivity. Cole (2005) suggests that employees' performance in an organization is evident by attainment of set goals, reduced labour turnover, reduced absenteeism and late coming and early leaving of an organization. This comes as a result of employees' motivation from job restricting which cuts down boredom due to undertaking of a repetitive job without a change.

\section{Conceptual Framework}

The conceptual framework hypothesized that job enlargement influences employee performance. The independent variable indicators included task structuring, job arrangement and the meaningfulness of a job. The dependent variable was employee performance.

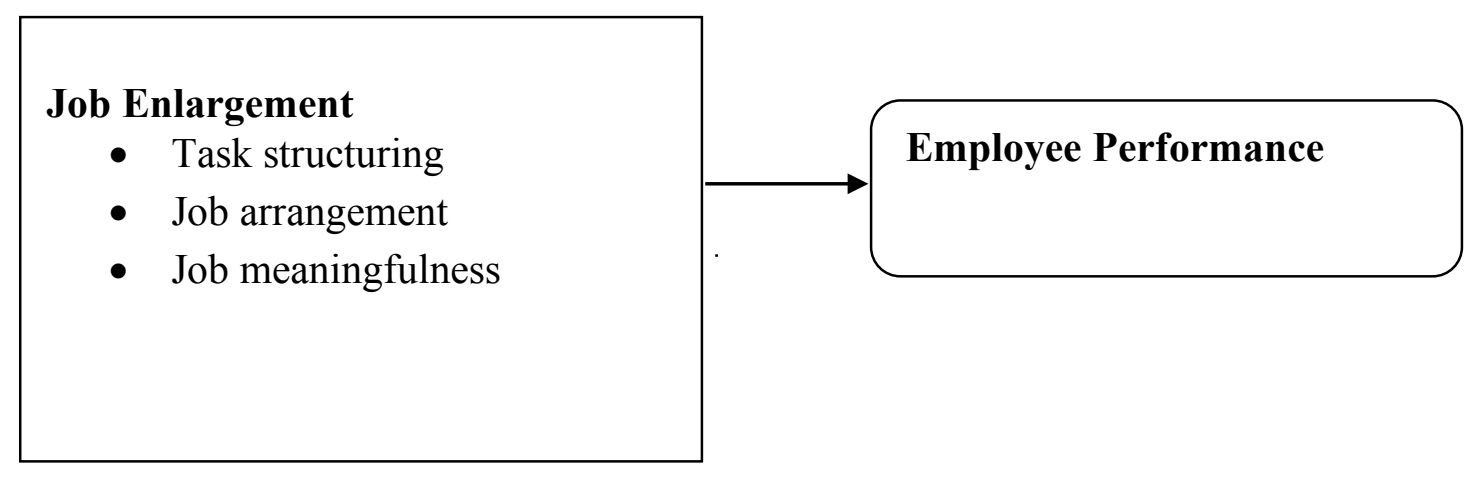

\section{RESEARCH METHODOLOGY}

The study adopted a descriptive survey research design in establishing the effect of job enlargement on employee performance at the railway company. According to the human 
resource department, the organization has 2,000 employees. Systematic sampling technique was used to pick a sample. The study sampled every fifth employee. This constituted a sample size of 400 employees which was arrived at by taking $20 \%$ of the 2000 employees. In this study primary sources were used in collection of data. The questionnaire as the data collection instrument was divided into three sections; section one was used to collect demographic information, section two was used to collect information on job enlargement and section three comprised questions on employee performance. The respondents were given two days to fill in the questionnaires i.e. the questionnaires were administered through a drop and pick later method. Data was analyzed through descriptive statistics such as frequencies and percentages. Regression analysis was done to determine the influence of job enlargement on employee performance. Data was presented in form of tables and graphs. The following regression model was adopted:

Where;

$$
\mathrm{Y}=\mathrm{b}_{0}+\mathrm{b}_{1} \mathrm{X}_{1}+\mathrm{b}_{2} \mathrm{X}_{2}+\mathrm{b}_{3} \mathrm{X}_{3}+\varepsilon
$$

$\mathrm{Y}=$ Employee Performance

$\mathrm{b}_{0}=$ constant

$b_{1} \ldots . . . b_{3}=$ regression coefficients

$\mathrm{X}_{1}=$ Task structuring

$\mathrm{X}_{2}=$ Job arrangement

$\mathrm{X}_{3}=$ Job Meaningfulness

$\varepsilon=$ error term

\section{Response Rate}

\section{DATA ANALYSIS AND RESULTS}

Out of the 400 questionnaires that were distributed to the respondents, 280 were successfully filled and returned. This represents a response rate of $70 \%$ which the researchers considered to be sufficient. This view is supported by Sekaran (2008) who posited that a response rate that exceeds $50 \%$ is sufficient for conducting analysis.

\section{Demographic Data}

The demographic data of the respondents have been discussed in this section. This includes gender, age, the level of education and experience.

\section{Gender of the Respondents}

The participants were requested to state their gender. The outcome is presented in Table 4.1.

Table 4.1 Gender of the Respondents

\begin{tabular}{lll}
\hline Gender & Frequency & Percentage \\
\hline Male & 168 & 60 \\
Female & 112 & 40 \\
\hline Total & 280 & 100 \\
\hline
\end{tabular}

In Table 4.1, majority (60\%) of the respondents were male while the rest (40\%) were female. This implied that majority of the employees who worked for the company were male.

\section{Age Bracket}

The researchers inquired from the participants about their age brackets. The output is captured in Table 4.2 . 
Table 4.2 Age brackets of the Respondents

\begin{tabular}{lll}
\hline Age & Frequency & Percentage \\
\hline Below 25 years & 00 & 00 \\
26-35 years & 40 & 14 \\
36-45 years & 55 & 20 \\
46-55 years & 120 & 43 \\
56 years and above & 65 & 23 \\
\hline Total & 280 & 100 \\
\hline
\end{tabular}

In Table 4.2, most of the respondents (43\%) were aged between 46 to 55 years, $23 \%$ of the respondents were over 56 years, 20\% were aged between 36-55 years and only, 14\% of the respondents were aged between 26-35 years. None of the target population fell in the age bracket of below 25 years. This implies that the employees working for the company had adequate experience and are mature.

\section{Educational Level}

The participants were requested to indicate the level of education. The findings are presented in Table 4.3.

Table 4.3 Educational Level

\begin{tabular}{lll}
\hline & Frequency & Percentage \\
\hline Primary & 00 & 00 \\
Secondary & 30 & 10 \\
Tertiary & 150 & 54 \\
University & 100 & 36 \\
\hline & 280 & 100 \\
\hline
\end{tabular}

The output in Table 4.3 showed that majority (54\%) of the respondents were college graduates, $36 \%$ of the respondents were university graduates and only $10 \%$ were form four leavers. None of the respondents had only primary school qualification.

\section{Job Category}

The respondents were asked to tick their job category in the organization. The results are shown in Table 4.4.

Table 4.4 Job Category

\begin{tabular}{lll}
\hline & Frequency & Percentage \\
\hline Executive & 02 & 1 \\
Management & 60 & 21 \\
Non-Management & 218 & 78 \\
\hline & 280 & 100 \\
\hline
\end{tabular}

The results in Table 4.4 depicts that majority (78\%) of the respondents were non-management staff, $21 \%$ were management staff while only, $1 \%$ of the respondents were the top management executive.

\section{Length of Service in the Organization}

The respondents were asked to indicate the duration that they had served in the organization. These results are provided in Table 4.5. 
Table 4.5 Length of Service in the Organization

\begin{tabular}{lll}
\hline & Frequency & Percentage \\
\hline $0-5$ years & 05 & 01 \\
6-10 years & 25 & 09 \\
11-15 years & 150 & 54 \\
Over 15 years & 100 & 36 \\
\hline & 280 & 100 \\
\hline
\end{tabular}

Table $4.5,54 \%$ of the respondents had served between $11-15$ years in the organization, $36 \%$ had served for over 15 years, 9\% had served between 6-10 years and only $1 \%$ of the respondents had served between 0-5 years. This was an indication that most of the employees working for the company had served for duration of more than 10 years and had adequate knowledge and experience about the organization.

\section{Job Enlargement}

Under this section, the researcher determined several aspects regarding job enlargement. The study looked at various aspects of job enlargement which included task structuring, job arrangement and meaningfulness of a job.

\section{Task Structuring}

The researchers sought to determine several aspects of task structuring. The results are provided in Table 4.6.

Table 4.6 Task Structuring

\begin{tabular}{llll}
\hline & $\mathrm{N}$ & Mean & Std. Deviation \\
\hline $\begin{array}{l}\text { The employees are clear about their tasks in all } \\
\text { the organizational Levels }\end{array}$ & 280 & 3.861 & 0.692 \\
$\begin{array}{l}\text { Employees understand the processes and } \\
\text { procedures }\end{array}$ & 280 & 3.561 & 0.907 \\
$\begin{array}{l}\text { Employees are motivated to perform their tasks } \\
\begin{array}{l}\text { The management has a role to analyze and } \\
\text { restructure a task }\end{array}\end{array}$ & 280 & 3.611 & 0.853 \\
$\begin{array}{l}\text { The organization has a well-defined task } \\
\text { structure }\end{array}$ & 280 & 3.910 & 0.727 \\
\hline Total & 280 & 3.254 & 0.544 \\
\hline
\end{tabular}

The results revealed that employees were clear regarding their tasks in all levels of the organization as indicated by a mean of 3.861. A mean of 3.561 was an indication that employees understood the processes and procedures of work. Further, the results revealed that employees were motivated to execute their tasks as shown by a mean of 3.611. The top management was mandated to restructure tasks and analyze roles and this was supported by a mean of 3.9 and that the organization comprised of a well-defined task structure as shown by a mean of 3.254. The Grand mean was 3.639 with a standard deviation of 0.745 . This was an indication that the respondents agreed that task structuring enhanced employees' performance in the organization.

\section{Job Arrangement}

The researchers sought to establish several aspects of job arrangement. The results are shown in Table 4.7. 
Table 4.7 Job Arrangement

\begin{tabular}{llll}
\hline & $\mathrm{N}$ & Mean & Std. Deviation \\
\hline $\begin{array}{l}\text { The organization combines various aspects of a job } \\
\text { (planning, controlling and executing) }\end{array}$ & 280 & 3.561 & 0.754 \\
$\begin{array}{l}\text { The management is entrusted to plan and control } \\
\text { job }\end{array}$ & 280 & 3.671 & 0.421 \\
$\begin{array}{l}\text { Employees are responsible for task execution } \\
\begin{array}{l}\text { Employees are offered opportunities for career } \\
\text { advancement }\end{array}\end{array}$ & 280 & 3.652 & 0.432 \\
Employee enjoy work-life balance & 280 & 3.785 & 0.495 \\
\hline Total & 280 & 3.698 & 0.523 \\
\hline
\end{tabular}

The findings showed that the organization combines various aspects of a job such as planning, controlling and execution. This was supported by a mean of 3.51. The findings also showed that the management was entrusted in planning and control. This was presented by a mean of 3.671. A mean of 3.652 showed that employees were responsible for task execution. Further the findings showed that employees were offered opportunities to develop their career and they also enjoyed work-life balance as indicated by a mean of 3.821 and 3.785 respectively. The Grand mean was 3.698 with a standard deviation of 0.523 . This was an indication that the respondents agreed that job arrangement influenced performance of employees in the organization.

\section{Job Meaningfulness}

The study sought to establish some aspects of job meaningfulness. The outcome is depicted in Table 4.8.

Table 4.8 Job Meaningfulness

\begin{tabular}{llll}
\hline & $\mathrm{N}$ & Mean & Std. Deviation \\
\hline $\begin{array}{l}\text { Employees possess a set of skills } \\
\text { Employees get job allocation is based on the skills }\end{array}$ & 280 & 3.312 & 0.714 \\
and knowledge & 280 & 2.965 & 0.654 \\
$\begin{array}{l}\text { Employees enjoy job autonomy in the organization } \\
\text { The organization does performance appraisal to }\end{array}$ & 280 & 3.592 & 0.632 \\
improve the quality of input of employees & 280 & 3.912 & 0.561 \\
Employees are highly motivated in their work & 280 & 3.265 & 0.781 \\
\hline Total & 280 & 3.409 & 0.668 \\
\hline
\end{tabular}

The output revealed that the employees possessed a set of skills and job allocation was based on employees' skills and knowledge as indicated by a mean of 3.312 and 2.965 respectively. Employees enjoyed independence in their work as was shown by a mean of 3.912. A mean of 3.265 was an indication that employees are highly motivated in their work. The grand mean was 3.409 and a standard deviation of 0.668. This implied that the respondents were neutral with regard to whether job meaningfulness contributed to employees' performance in the organization.

\section{Employee Performance}

The study sought to establish some aspects of employee performance and the results are captured in Table 4.9. 
Table 4.9 Employee Performance

\begin{tabular}{|c|c|c|c|}
\hline & $\mathbf{N}$ & Mean & Std Deviation \\
\hline The organization rewards good performance & 280 & 3.714 & 0.781 \\
\hline I meet deadlines as set & 280 & 3.574 & 0.627 \\
\hline $\begin{array}{l}\text { The organization sponsor trainings and development } \\
\text { programmes to boost performance }\end{array}$ & 280 & 3.761 & 0.642 \\
\hline $\begin{array}{l}\text { The tools and resources needed to do my job are } \\
\text { sufficient }\end{array}$ & 280 & 3.621 & 0.782 \\
\hline $\begin{array}{l}\text { Organizational culture provides a conducive environment } \\
\text { to work }\end{array}$ & 280 & 3.815 & 0.514 \\
\hline The organization does performance appraisal & 280 & 3.910 & 0.735 \\
\hline \multirow[t]{2}{*}{$\begin{array}{l}\text { The top management is supportive and this encourages } \\
\text { employees to achieve their targets }\end{array}$} & 280 & 2.933 & 0.553 \\
\hline & 280 & 3.618 & 0.662 \\
\hline
\end{tabular}

Table 4.9 depict that the respondents agreed that; the organization did performance appraisal, its culture gave employees a comfortable environment, the organization funded training programs, performing employees were rewarded, employees were provided with facilities and resources and that they accomplished their deadlines. Mean scores were $(3.910,3.815,3.761$, $3.714,3.621$ and 3.574 respectively). The respondents remained neutral regarding the support they got from top management in assisting them to attain their targets. The mean value was 2.933. It was concluded that employees performed. Grand mean value was 3.618 and a standard deviation of 0.662 .

\section{Job enlargement and Employee performance}

A regression equation was adopted in testing the hypothesis on the link between job enlargement and employee performance at the company. The output is provided as follows:

Table 4.9: The Summary of the Model Model Summary

\begin{tabular}{llrrr}
\hline Model & R & R Square & $\begin{array}{c}\text { Adjusted R } \\
\text { Square }\end{array}$ & $\begin{array}{l}\text { Std. Error of } \\
\text { the Estimate }\end{array}$ \\
\hline 1 & $.673^{\text {a }}$ & .497 & .442 & .01720 \\
\hline a. Predictors: (Constant), task structuring, job \\
arrangement, job meaningfulness
\end{tabular}

The output depicted in Table 4.9 discovered that the coefficient of determination was 0.497 which signaled that job enlargement explained $49.7 \%$ variations in employee performance.

Table 4.10: Analysis of Variance ANOVA $^{\mathrm{a}}$

\begin{tabular}{llrrrrr}
\hline \multicolumn{2}{l}{ Model } & \multicolumn{2}{c}{ Sum of } & \multicolumn{2}{c}{ Mean } \\
Squares & df & \multicolumn{2}{c}{ Square } & \multicolumn{1}{c}{ F } & \multicolumn{1}{c}{ Sig. } \\
\hline 1 & Regression & 0.118 & 3 & .039 & 2.786 & $.000^{\mathrm{b}}$ \\
& Residual & 4.012 & 276 & .014 & & \\
& Total & 4.130 & 279 & & & \\
\hline
\end{tabular}

a. Dependent Variable: employee performance

b. Predictors: (Constant), task structuring, job arrangement, job meaningfulness

The outcome in Table 4.10 portrayed that the regression equation utilized in this research was 
significant since it contained predictive values. P-value was smaller than $5 \%, 0.000$.

Table 4.11 Model Coefficients

Coefficients $^{\mathrm{a}}$

\begin{tabular}{llrrrrr}
\hline & & \multicolumn{2}{l}{$\begin{array}{l}\text { Unstandardized } \\
\text { Coefficients }\end{array}$} & \multicolumn{2}{c}{$\begin{array}{c}\text { Standardized } \\
\text { Coefficients }\end{array}$} & \\
Model & B & Std. Error & Beta & \multicolumn{1}{c}{ t } & \multicolumn{1}{c}{ Sig. } \\
\hline $1 \quad$ & (Constant) & -.026 & .016 & & -1.512 & .139 \\
& $\begin{array}{l}\text { Task } \\
\text { structuring }\end{array}$ & .067 & .015 & -.479 & -4.395 & .000 \\
& $\begin{array}{l}\text { Job } \\
\text { arrangement }\end{array}$ & .039 & .034 & .145 & 1.170 & .236 \\
$\quad \begin{array}{l}\text { Job } \\
\text { meaningfulness }\end{array}$ & -.011 & .016 & -.077 & -.681 & .500 \\
\hline
\end{tabular}

a. Dependent Variable: employee performance

The regression model derived from this study is as follows:

$$
\text { Employee performance }=-0.026+0.067 \mathrm{X}_{1}+0.039 \mathrm{X}_{2}-0.011 \mathrm{X}_{3}+\varepsilon
$$

Task structuring and job arrangement were positively linked to employee performance $[0.067$ $\& 0.039$, respectively). This signaled that a single increase in any of these variables resulted into a corresponding increase in employee performance. Job meaningfulness was inversely linked to employee performance $(-0.011)$. This implied that a unit increase in this variable led to a corresponding decrease in employee performance.

Task structuring was significant since its p-values was less than $5 \%,(0.000)$ while job arrangement and job meaningfulness were insignificant since their p-values exceeded $5 \%$, i.e. $23.6 \%$ and $50.0 \%$ respectively.

\section{DISCUSSION AND CONCLUSIONS}

Concerning the various aspects of job enlargement, the respondents agreed that task structuring and job arrangement contributed towards improving the performance of employees. These findings are in line with the suggestions made by Jackson et al., (2009) and Tejinder et al., (2013), who argued that task structuring and job arrangement enabled the organization to align tasks, employees easily understood processes and procedures and this acted as a strong motivator for them to work harder and realize organizational goals.

There was no agreement as to whether job meaningfulness improved employee performance. The respondents argued that having a set of various skills did not necessarily contribute to performance. Further, they pointed out that job autonomy had little contribution on employees' performance. On the contrary, allocation of work based on knowledge and skills improved employees' efficiency in the execution of tasks. These findings are supported by Robertson (1992) who observes that hiring the right employees for the right job increases employee productivity as opposed to possessing multiple skills.

Task structuring was significant since their probability values were less than 5\%, (0.000). These findings are consistent with the views of Tejinder (2013) who found that task structuring was significant. Job arrangement and meaningfulness were insignificant since their p-values were greater than, $5 \%(0.236 \& 0.500)$. These results concur with Garg and Rastogi 
(2006) who concluded that the manner in which the job was arranged in an organization did not affect the performance of the employees.

The study found that job enlargement aspects namely task structuring and job arrangement contributed towards employee performance. These two aspects enable employees to recognize their tasks, understand processes, motivate and achieve work-life balance, this boosts employees' efficiency, motivation and commitment to work and achieve their set targets. With regard to job meaningfulness; multiple skills, job autonomy and performance appraisal did not fully warrant an improvement in employees' performance.

\section{RECOMMENDATIONS}

The government should sponsor continuous training and development programmes to the top management of all parastatal bodies on matters of job enlargement and how it can be aligned to enhance employee performance. Thus, top management will gain knowledge and skills on employee job allocation, monitoring and supervision and thus contribute towards better planning and decision making on job enlargement.

The company should offer recognition and rewards to its employees as a way of encouraging them to work harder and perform their duties. This way, the employees will perform their duties efficiently with minimal supervision leading to a reduction in supervision cost.

The company should consider adopting a flexible organizational structure in which decisions and organizational functions can be decentralized in order to achieve flexibility in processes and procedures. This will enable employees to easily identify their tasks in the management levels, appreciate processes and motivate them to execute their tasks.

A comparable study ought to be conducted in the private sector in Kenya to determine the variation in responses. This would be useful in enabling the researcher to enhance the quality of the findings through comparison and thereafter a more detailed conclusion may be drawn. A study can be conducted on the effect of job enlargement on overall organizational performance considering both financial and non-financial measures of performance.

\section{References}

Abid, (2013). Effect of job design on employee satisfaction (a study of fertilizer companies listed in Lahore stock exchange, European Journal of Business and Management, 5, 19

Armstrong, M. (2006). A handbook of human resource management practice, $9^{\text {th }}$ Edition, Kogan Page, London. Aswathappa, K. (2006). Job analysis and job design: human resource and personal satisfaction, organizational commitment and performance: A survey of public secondary schools in Dagoretti division, Nairobi, unpublished MBA project, University of Nairobi.

Beardwell, J., \& Claydon, T. (2003). Human resource management contemporary Approach, 5th Edition, Prentice Hall.

Bielby, W. T., \& Baron, J. N. (2010). Men and women at work: Sex segregation and statistical discrimination, American Journal of Sociology, 91(4), 759-799.

Chard, L., (2004), Organizational theory, change \& design, 4th edition, South-Western A part of Cengage learning, India.

Cole, G.A. (2002). Personnel and human resource management, 5th Edition, Wiley, New York, NY.

Dessler G., (2008). Human resource management, 11 th Edition, Pearson Prentice Hall, New York, USA.

Faturochman, (1997). The job characteristics theory, A review, 1-13

Foot M., \& Hook C., (2008). Introducing human resource management, $5^{\text {th }}$ Edition, Pearson, Education Limited, Harlow, UK. 
Fried, Y., \& Ferris, G. R. (1987). The validity of the job characteristics model: a review and meta-analysis, Personnel Psychology, 40 (287-322).

Garg, P., \& Rastogi, R. (2006). New model of job design: motivating employees' performance, Journal of Management Development, 25, 572-587.

George, J.M., \& Jones, G.R. (1996). Understanding and managing organizational behavior reading, Massachusetts: Addison-Wesley Publishing Company

Gilmore S., \& Williams S., (2009), Human resource management, Oxford University Press, New York, USA.

Gomez-Mejia, L., Balkin D., \& Cardy R., (2010). Managing human resources, $6^{\text {th }}$ Edition,

Graham, H. T., \& Bennet, R. (1998). Human resource management, 9th Edition; Prentice Hall, Pearson education, Edinburg.

Hackman, J., \& Oldham, G. (1976) Motivation through the design of work: test of a theory. Organizational Behavior and Human Performance, 250-279.

Hackman, J., Lawler, E., \& Oldham, G. R. (2000). Job characteristics theory, In Miner, J

Hackman, J.R., \& Oldham, G.R. (1980) Work redesign. Readings, MA: Addison-Wesley.

Heilman, M. E. (2011). Sex bias in work settings: The lack of fit model', Research in Organizational Behavior, 5, 269-298.

Herzberg, F. (1974). Motivation-hygiene profiles: Pinpointing what ails the organization.

Hitt, M. A., \& Barr, S. H. (2010). Managerial selection decision models: Examination of configural cue processing', Journal of Applied Psychology, 74(1), 53-61.

Ivancevich, J. M. (1998). Job analysis and job design: Human resource management $7^{\text {th }}$ edition, Irwin: McGraw-Hill., 168-195.

Jonge, J., \& Bakker, A. (2009). Specific determinants of intrinsic work motivation, burnout, and turnover intentions: a study among nurses, Journal of Advanced Nursing, 296, 1360-9.

King, M., Michael, A.M., \& Atkinson, T. (1982). Background, personality, job characteristics, and satisfaction with work in a national sample, Human Relation.

Koys, D. J. (2011). The effects of employee satisfaction, organizational citizenship behavior, and turnover on organizational effectiveness: A unit-level, longitudinal study, Personnel Psychology, 54, 101-114.

LaLopa, J.M. (2007). The prediction of organizational commitment and turnover in resort jobs, Journal of Hospitality and Tourism Research, 21, 11-26.

Lee, R., \& Wilbur, E.R. (1985). Age, education, job tenure, salary, job characteristics, and job satisfaction: a multivariate analysis, Human Relations, 38 (8), 781-791.

Liden, R. C., \& Parsons, C. K. (2011). 'A field study of job applicant interview perceptions, alternative support groupies, and demographic characteristics, Personnel Psychology, 39, 109-122.

Managing human resources, $11^{\text {th }}$ edition, south-western, Cengage Learning, Mason, USA.

Marchant, T. (1999). Strategies for improving individual performance and job satisfaction at Meadowvale health, Journal of Management Practice, 2(3), 63-70.

Mitchell, T.R. (1982). Motivation: New direction for theory, research, and practices, Academy of Management Review, 7, 80-8.

Morrison, E.W. (2004). Role definitions and organizational citizenship behavior: the importance of the employee's perspective, Academy of Management Journal, 37 (6), 1543-67.

Mowday, R.T. (2009). Reflections on the study and relevance of organizational commitment, Human Resource Management Review, 8(4), 387-401.

Njenga, I. K. (2007). Relationship between human resource management practices, Job Organizational Behavior, Essential theories of motivation and leadership, M.E. Organizational Dynamics, 3(2), 18-29.

Orodho, A.J. \& Kombo, D.K. (2003). Research methodology, Nairobi Kenyatta University Institute of open learning.

Orpen, (2010). .Job enlargement, individual differences, and worker responses: A test with black workers in South Africa, Journal of Cross-Cultural Psychology, 7, 473-480, 
Price A., (2007). Human resource management in a business context, $3^{\text {rd }}$ Edition, Cengage Learning EMEA, Hampshire, UK.

Rankin N., (2003). Best practice in human resources handbook, Eclipse Group Limited, Hampshire, UK.

Sekaran, U. (2008). Research methods for business: a skill building approach, (4thEd.). London: John Wiley \& Sons

Smith, P. C. (1992). In pursuit of happiness, In: Cranny, C. J., Smith, P. C. and Stone, E. F. (Eds) Job Satisfaction, Lexington, New York.

Tejinder, K. Billing, R., Bhagat, S., \& Babakus, E. (2013). Task structure and work outcomes: Exploring the moderating role of emphasis on scheduling, Management Research Review, 36, 2.

Torrington, D., Hall, L., \& Taylor, S. (2008). Human resource management, $7^{\text {th }}$ edition, financial times, Prentice Hall, England, Great Britain.

Tsui, A., Egan, T., \& O'Reilly, C. (2009). Being different: Relational demography and organizational attachment', Administrative Science Quarterly, 37, 549-588.

Vaydanoff, P. (1980). Perceived job characteristics and job satisfaction among men and women, Psychology of Women Quarterly, 5(2), 177-185

Wiley, C. (2005).What motivates employees according to over 40 years of motivation surveys, MCB University Press, International Journal of Manpower, 18, 263-280. 